\title{
Resenha
}

\section{Conflito e liberdade!}

Conflict and freedom!

CONFLITO. Direção, roteiro e produção: José Roberto Novaes. Argumento: Carlita da Costa e César Lima. Rio de Janeiro: Projeto Educação através das Imagens/UFRJ, 2012. (Filme documentário: 20 min. - Distribuidora: Editora da UFRJ $<$ www.editora.ufrj.br >)

Beto Novaes, economista e cineasta, apresenta o novo documentário Conflito, resultante de suas pesquisas e intervenções sobre o trabalho e os trabalhadores do campo ${ }^{1}$, em especial na produção da cana-de-açúcar.

O objeto do filme é um conflito entre trabalhadores e representantes de uma usina de cana de açúcar, no interior de São Paulo, motivado pelas péssimas condições de vida e trabalho que levaram os trabalhadores a pleitear sua volta à Paraíba e ao Ceará, à terra natal. As lentes focam, sobretudo, a ação dos sindicalistas, em particular a da presidenta do sindicato de Cosmópolis, na coordenação da greve, em suas interações com trabalhadores e com representantes da empresa. São filmadas assembleias dos trabalhadores, locais de trabalho e de vivência (refeitórios, banheiros, alojamentos, transporte e fornecimento de água), trechos de negociações e entrevistas com o Procurador do Ministério Público do Trabalho, que fez a mediação entre trabalhadores e representantes da empresa.

A filmagem dos locais de moradia e vivência mostra a materialidade da relação de trabalho caracterizada pela exploração da força de trabalho e pelo desrespeito aos direitos mínimos dos trabalhadores - sujeira, precariedade e insalubridade da água - e provoca, no público que a assiste, indignação!

Para complementar suas filmagens, o autor recorre às imagens produzidas pelos próprios trabalhadores envolvidos no conflito, que reforçam seu caráter etnográfico (DENZIN, 1997) e revelam a dureza da realidade vivida por eles.

Poderíamos parar por aqui, mas o filme é mais do que a descrição do conflito, de seus determinantes e de seu desfecho: o acordo que permitiu aos trabalhadores retornarem para suas terras.

No caso em tela, como o trabalho não é condição para "se andar a vida", mas, ao contrário, coloca-a em grave risco, é preciso negá-lo e conquistar o direito de voltar para casa por meio da resistência e da luta, da intervenção precisa do sindicato e da intermediação do Estado. Encontramo-nos aqui no seio das questões que movimentam o campo da Saúde, Trabalho e Direito (VASCONCELOS; OLIVEIRA, 2011).
Dessa forma, a ação (o trabalho) dos dirigentes sindicais, em especial de sua presidenta, e seu engajamento na defesa do interesse dos trabalhadores, a resistência do coletivo ante a exploração, a emancipação e a conquista dos seus direitos por meio da luta ocupam papel central na narrativa.

O filme cumpre, assim, com o que se espera de obra desta natureza, isto é, não se trata apenas de interpretação plausível da realidade e dos caminhos para o enfrentamento da exploração (ou da "morte açucarada", segundo Francisco de Oliveira, 2007, p. 07), mas expressa a beleza da intervenção corajosa da dirigente sindical e da força da resistência coletiva, descrevendo, de forma artística, a ação humana legítima.

Dos gritos em coro - "O povo unido jamais será vencido" -, ao final do filme, não resta apenas o conflito na memória de quem o assiste, mas se guarda a imagem da luta, da emancipação e da busca da liberdade.

Somos, enfim, levados, ao longo do filme, junto com os trabalhadores que voltam para casa, do CONFLITO à LIBERDADE!

\section{Referências}

DENZIN, N. Interpretative ethnography. Ethnographic practices for the 21st century. London: Sage, 1997.

NOVAES, J. R.; ALVES, F. (Orgs.) Migrantes. Trabalho e trabalhadores no Complexo Agroindustrial Canavieiro (os heróis do agronegócio brasileiro). São Carlos: EdUFSCar, 2007.

OLIVEIRA, F. Prefácio. In: NOVAES, J. R.; ALVES, F. (Orgs.) Migrantes. Trabalho e trabalhadores no Complexo Agroindustrial Canavieiro (os hérois do agronegócio brasileiro). São Carlos: EdUFSCar, 2007. p. 7-9.

VASCONCELOS, L. C. F.; OLIVEIRA, M. H. B. (Orgs.) Saúde, trabalho e direito: uma trajetória crítica e a crítica de uma trajetória. Rio de Janeiro: Educam, 2011. 